\title{
Extraction and Characterization of the Polar Lipid Fraction of Blackberry and Passion Fruit Seeds Oils Using Supercritical Fluid Extraction
}

\author{
David Arturo-Perdomo ${ }^{1}$ - Juan Pablo Jiménez Mora ${ }^{1}$ - Elena lbáñez ${ }^{2}$ - Alejandro Cifuentes ${ }^{2}$. \\ Andrés Hurtado-Benavides ${ }^{1} \cdot$ Lidia Montero $^{3,4}$ (D)
}

Received: 22 October 2020 / Accepted: 5 April 2021 / Published online: 21 April 2021

(C) The Author(s) 2021

\begin{abstract}
The study of the phytochemical composition of seed oils is of upmost importance for the food and cosmetic industries, mainly considering their associated biological properties. Extraction of seed oils using supercritical fluids (SFE) is an ecological and green alternative to conventional extraction processes since it is able to provide with potent bioactive extracts, avoiding degradation and transformation of the compounds present originally in the raw material. The objective of the present work was the extraction of pure fractions of polar lipids and their chemical characterization using chromatographic techniques such as GC-MS and LC-DAD-MS/MS of blackberry (Rubus glaucus) and passion fruit (Passiflora edulis) seed oils extracted by supercritical carbon dioxide. Oleamides derived from oleic acid were identified as the main compounds in both samples; in particular, 9octadecenamide was the major identified oleamide. Besides, the extract obtained from passion fruit showed to be a source of linoleic acid, while the SFE extract from blackberry presented important concentrations of vanillin. The chemical composition of these seed oils can be of high interest for their further use in cosmetics and food industry.
\end{abstract}

Keywords Fruit by-product $\cdot$ SFE $\cdot$ Oleamides $\cdot$ Passiflora edulis $\cdot$ Rubus glaucus $\cdot$ GC-MS

\section{Introduction}

Vegetable seed oils are mainly composed of triacylglycerides (TAGs), representing between 95 and $98 \%$ of their chemical composition. Other minor components such as sterols, tocopherols, mono- and diglycerides, carotenes, and polyphenols are also present and have been associated to an interesting biological activity of these oils. TAGs are composed by one molecule of glycerol esterified with three fatty acids (unsaturated or polyunsaturated). The unsaturated fatty acids are very

Lidia Montero

lidia.montero@uni-due.de

1 Grupo de Investigación Tecnologías Emergentes en Agroindustria, Facultad de Ingeniería Agroindustrial, Universidad de Nariño, P.O. Box 1175, Pasto, Colombia

2 Foodomics Laboratory, Institute of Food Science Research (CIAL, CSIC-UAM), Nicolás Cabrera 9, 28049 Madrid, Spain

3 Applied Analytical Chemistry, University of Duisburg-Essen, Universitaetsstr. 5, 45141 Essen, Germany

4 Teaching and Research Center for Separation (TRC), University of Duisburg-Essen, Universitaetsstr. 5, 45141 Essen, Germany important compounds for nutritional and metabolic functions in the organism since they play an important role in the regulation of a variety of physiological and biological functions (Sanchez-Salcedo et al. 2016). Polyunsaturated fatty acids (PUFAs) are important for antioxidant, vascular, and antiinflammatory properties (omega 3, 6, 9) (Opie et al. 2017). Besides, omega-3 fatty acids have shown anti-cancer prevention properties (Bodkowski et al. 2014; Sokoła-Wysoczańska et al. 2018). Likewise, its properties for the prevention of cardiovascular diseases are well recognized, mainly the omega-3 long-chain polyunsaturated fatty acids (18-22 carbon chain) family (Sokoła-Wysoczańska et al. 2018), that have been also associated to other health benefits related to skin diseases, arthritis, respiratory system diseases as asthma, lupus erythematosus, or multiple sclerosis (Abedi and Sahari 2014). Therefore, fruits seed are considered a valuable byproduct in the food industry that can be used for the development of new food products with improved nutritional characteristics (Villacís-Chiriboga et al. 2020).

Andean fruits have great potential value in terms of production and consumption for the agroindustrial field. The production of passion fruit in Colombia in 2019 was $137.456 \mathrm{t}$ and represented 12.365 ha of the total cultivated area. At 
present, the fruit is commercialized as fresh fruit or preserved fruits. Concerning blackberry, the total production in 2019 reached 137.999 t occupying 15.902 ha of the cultivated area. The $55 \%$ of the blackberry production is destined to fresh fruit household consumption, while about $20 \%$ is sold to the agroindustry for the preparation of juices, pulps, preserved food fruits candies, and colorants (SIOC 2021). The oil from Passiflora seeds has considerable content of unsaturated fatty acids (Ballesteros-Vivas et al. 2019a; Ramaiya et al. 2019; Cuong et al. 2019; Pantoja-Chamorro et al. 2017a) being an important source of these compounds for the cosmetic and food industries (Malacrida and Jorge 2012; PantojaChamorro et al. 2017b). The cosmetic industry appreciated the natural products with a high content of linoleic and linolenic acid for the high antioxidant and skincare properties (Urbanavičiūtè et al. 2019). Likewise, blackberry seed oils are an important source of unsaturated fatty acids as well (Pantoja-Chamorro et al. 2017b; Sanchez-Salcedo et al. 2016; Kitryte et al. 2020); thus, the oils of blackberry fruit also have antioxidant, pharmaceutical, and food promising properties.

Fatty acid amides are compounds derived from fatty acids principally from oleic (oleamide), stearic (steramide), and linoleic (linoleamide) acids. Many properties have been described for these compounds, such as relevant effects on thermoregulation, analgesic activity in experimental models, and various biochemical activities (Cheng et al. 2010). Zeid et al. (2019) studied the use of 9-octadecenamide (oleamide) as a potential medicinal treatment for mood and sleep disorders. Also, different authors have reported that oleamide has cannabinoid-like activities (Oh et al. 2010; Cheng et al. 2010; Sudhahar et al. 2009). Other properties described in many works for oleamide are anti-inflammatory (Moon et al. 2018), influence in some mechanisms of the cardiovascular system (Hiley and Hoi 2007) as well as diuretic, carminative, and astringent properties (Nazeam et al. 2018; Tanvir et al. 2018).

Most of the effort carried out on the chemical composition of seed oils has been focused on the analysis of the non-polar fraction containing fatty acids, sterols, tocopherols, and diacylglycerols, while the study of more polar compounds such as fatty acid amides is really scarce (Amri et al. 2017). The main reason for this lack of information about the comprehensive characterization of the seed oils is the complex composition regarding the different families of compounds that present a wide range of polarities making both, the extraction and the chemical characterization a real challenge.

In the last years, supercritical fluid extraction (SFE) using carbon dioxide as extraction solvent has received special attention for the extraction of seed oils. SFE is an environmentally friendly technology that provides with important advantages compared to conventional extraction processes. The extraction yield and selectivity depend on different factors such as the technique and the extraction parameters employed and the type of solvent or the geographical area where the fruits are grown (Pantoja-Chamorro et al. 2017a). SFE employs green solvents such as carbon dioxide and it commonly allows obtaining higher efficiency, selectivity, and recoveries working under mild conditions, thus favoring the extraction of bioactive and thermolabile compounds (Dorado et al. 2016; Herrero et al. 2006; Herrero et al. 2013).

Some manuscripts have been published focusing on the use of SFE for fruit's seeds oil extraction. Among them, the extraction conditions and chemical characterization of minor and major components of guava and passion fruits has been examined (Dorado et al. 2016; Castro-Vargas et al. 2010). Besides, the use of co-solvents for the extraction of antioxidant compounds and total phenols of guava seeds has been evaluated (Castro-Vargas et al. 2010) as well as the extraction of passion fruits seeds (Passiflora edulis sp.) using ultrasound-assisted SFE and the chemical analysis of major components such as fatty acids and tocopherols, tocotrienols, and antioxidant compounds (Manuel-Barrales et al. 2015). Moreover, fatty acids analysis and microencapsulation of blackberry seeds oil using supercritical $\mathrm{CO}_{2}$ has been also reported (Figueroa et al. 2016).

Recently, the extraction and chemical characterization of bioactive metabolites from Passiflora mollissima seeds (Ballesteros-Vivas et al. 2019b) and mango seed kernel (Ballesteros-Vivas et al. 2019a) combining pressurizedliquid extraction and gas/liquid chromatography-high resolution mass spectrometry have been reported; however, to the best of our knowledge, no reports can be found in the literature involving the use of selective supercritical fluid extraction conditions for the fractionation and extraction of the polar lipid fraction and its chemical characterization from tropical fruits seeds or fruits. In this sense, considering both, the potential biological activity of the extracts and the advantages of SFE technology in terms of greenness of the processes, versatility and efficiency, the possibility of employing SFE as an environmentally clean and sustainable process to obtain oils enriched in bioactive minor components, mainly polar lipids, from blackberry (Rubus glaucus) and passion fruit (Passiflora edulis) seed oils from the Andes Natural Region of South America was studied. The chemical characterization of the minor polar lipid fraction of the seed oil extracts was carried out using chromatographic techniques such as GC-MS and LC-DAD-MS/MS.

\section{Material and Methods}

\section{Samples and Reagents}

Passion fruit and blackberry seeds were supplied by Agroindustrial Products of Nariño (INPADENA), Pasto, 
Colombia. Supercritical seed oils extracts were obtained by the Laboratory of Supercritical Fluids and Natural Ingredients of the Emerging Technologies in Agroindustry research group of the Universidad de Nariño as described in "Extraction of the Seed Oils from Passion Fruit and Blackberry with Supercritical $\mathrm{CO}_{2}$." Ultrapure water was obtained from a Millipore system (Billerica, MA, USA), whereas HPLCgrade methanol and acetonitrile were purchase from VWR Chemicals (Barcelona, Spain) and carbon dioxide from Cryogas-Indura (Cali, Colombia).

\section{Extraction of the Seed Oils from Passion Fruit and Blackberry with Supercritical $\mathrm{CO}_{2}$}

SFE was carried out as described in a previous works by Pantoja-Chamorro et al. (2017a, 2017b). Briefly, samples were washed with water, then they were dried in a tray dryer (FIQ, Colombia) $8 \mathrm{~h}$ at $60^{\circ} \mathrm{C}$. The final moisture percentage was $7.60 \%$ and $7.8 \%$ for blackberry and passion fruit, respectively. The dried fruit seeds were ground with a grinder of hammers, blades, and discs, and they were stored at $4{ }^{\circ} \mathrm{C}$ until their use. The extractions were carried out using a pilot-scale SFE instrument (TharSFE-500 (Waters, USA)) equipped with a 0.5 -L extraction cell and two 0.5 -L separators with independent pressure and temperature controls. The determination of the optimal conditions was based on a kinetic study of the process. Two hundred and fifty grams of dried fruit seeds were used with a $\mathrm{CO}_{2}$ flow rate of $30 \mathrm{~g} \mathrm{~min}^{-1}$. Extraction conditions were as follow: 350 bar and $60^{\circ} \mathrm{C}$ for $150 \mathrm{~min}$. Extraction was carried out in duplicate with neat supercritical $\mathrm{CO}_{2}$. After extraction, the oil extracts were collected in vials and stored at $-20^{\circ} \mathrm{C}$ and protected from light until analysis.

\section{Sample Preparation for the Analysis of seed Oil Polar Fraction}

For the second step, the polar lipids were extracted from the SFE extract. One milliliter of $80 \%$ methanol was added to 200 $\mu \mathrm{L}$ of seed oils obtained under supercritical conditions. The sample was shaken at $6500 \mathrm{rpm}$ in a shaker and centrifuged for $5 \mathrm{~min}$ at $10000 \mathrm{rpm}$, following the methodology described by Koubaa et al. (2015). The upper phase (polar fraction) was recovered and was kept under refrigeration at $4{ }^{\circ} \mathrm{C}$ until chromatographic analysis. The extraction was done by triplicate for each sample.

\section{Determination of the Polar Lipids Percentage in Seeds Oils}

The percentage of polar lipids in the seed oils was determined by a gravimetric method previously described (Koubaa et al. 2015). The oil samples $(200 \mu \mathrm{L})$ and the final extract (polar fraction) were weighed in an analytical balance (Ohaus Pioneer).

\section{Analysis of the Seed Oils Polar Fraction by GC-MS}

The polar fractions obtained as described in "Sample Preparation for the Analysis of seed Oil Polar Fraction" were dried under nitrogen stream and dissolved in methanol for their GC-MS analysis. A GCMS-QP2010 plus system (Shimadzu, Kyoto, Japan) was employed for the analysis, and the separation was carried out on a DB-5 ms (30 $\mathrm{m} \times$ $0.25 \mathrm{~mm} \times 0.25 \mu \mathrm{m}$, Agilent, Tech, Santa Clara, USA) using helium as carrier gas at $1.0 \mathrm{~mL} \mathrm{~min}{ }^{-1}$. The separation was performed according to the following oven temperature program: initial temperature was $40^{\circ} \mathrm{C}$, then it was raised to 250 ${ }^{\circ} \mathrm{C}$ at $15^{\circ} \mathrm{min}^{-1}$ maintaining this temperature for $5 \mathrm{~min}$, followed by an increase to $300{ }^{\circ} \mathrm{C}$ at $10^{\circ} \mathrm{min}^{-1}$, finally this value was maintained for $20 \mathrm{~min}$. The injection volume was $1.0 \mu \mathrm{L}$ in splitless mode with the injector temperature set at $250^{\circ} \mathrm{C}$. The MS detection parameters were: interface temperature of $300^{\circ} \mathrm{C}$; source temperature of $230^{\circ} \mathrm{C}$; mass range $\mathrm{m} / \mathrm{z}$ of 40-500; scan speed of $2500 \mathrm{amu} \mathrm{s}^{-1}$; and event time of 0.20 $\mathrm{s}$. The analysis was carried out in triplicate. Data obtained in the analyses was handled using the GC-MS solution (ver. 2.71, Shimadzu) software. The identification of the compounds was carried out using commercial mass spectral database (Wiley and NIST) as well as their respective linear retention indices (LRIs) by the use of a hydrocarbon mixture ranging from $\mathrm{C}_{8}$ to $\mathrm{C}_{30}$ analyzed under the same conditions as the sample.

\section{Analysis of the Seed Oils Polar Fraction by LC-DAD- MS/MS}

Analyses were carried out on a Agilent 1200 series liquid chromatograph (Agilent Technologies, Santa Clara, CA, USA) equipped with a binary pump, an autosampler and a $\mathrm{DAD}$, coupled to an ion trap mass spectrometer (Agilent ion trap 6320) with an electrospray interface. A Zorbax Eclipse XDB-C18 $(4,6 \times 150 \mathrm{~mm}, 5 \mu \mathrm{m}$, Agilent 248 Technologies, Santa Clara, CA, USA) column was employed for the separation using (A) water ( $0.1 \%$ formic acid) and (B) acetonitrile as mobile phases and a gradient elution of $0 \mathrm{~min}, 10 \% \mathrm{~B} ; 20 \mathrm{~min}$, $20 \%$ B, $35 \mathrm{~min}, 30 \%$ B; $45 \mathrm{~min}, 60 \%$ B; $55 \mathrm{~min}, 90 \%$ B; 60 min, $90 \%$ B; $61 \mathrm{~min}, 100 \%$ B; $70 \mathrm{~min}, 100 \%$; $71 \mathrm{~min}, 10 \% \mathrm{~B}$; $75 \mathrm{~min}, 10 \% \mathrm{~B}$. The injection volume was $20 \mu \mathrm{L}$ and flow rate was established at $0.5 \mathrm{~mL} \mathrm{~min}^{-1}$. Analyses were registered at 280 and $330 \mathrm{~nm}$ and the UV-Vis spectra were acquired from 190 to $550 \mathrm{~nm}$. The MS was operated under ESI positive and negative ionization modes using the following setting: dry temperature $300{ }^{\circ} \mathrm{C}$, mass range $\mathrm{m} / \mathrm{z}$ 90-2200 Da, dry gas flow rate $12 \mathrm{~L} \mathrm{~min}^{-1}$, nebulization pressure $30 \mathrm{psi}$. 


\section{Results and Discussion}

\section{Determination of the Polar Lipid Percentage in Seeds Oils}

SFE is known as a selective extraction technique for non-polar fractions due to the physicochemical characteristics of carbon dioxide at supercritical conditions. However, by the modification of some extraction conditions such as temperature, pressure, extraction time, or the use of co-solvents, the solubility of more polar compounds in the supercritical $\mathrm{CO}_{2}$ can be improved, and therefore a more polar fraction can be extracted. In this work, 350 bar and $60^{\circ} \mathrm{C}$ for $150 \mathrm{~min}$ were used as extraction conditions to obtain the potential bioactive compounds present in the seed oils from blackberry and passion fruit. The extraction conditions selected accordingly with a kinetic study for the fruit seeds provided the optimal conditions to maximize the oil extraction yield. The relation between temperature, pressure and time in SFE determines the quantity and quality of the extract composition, making possible the careful modification of these parameters to achieve selective lipid extractions (Sahena et al. 2009). In this work, a strong pressure-temperature interaction working at 350 bar was observed, being the optimal conditions of pressure and temperature 350 bar and $60{ }^{\circ} \mathrm{C}$, respectively, which achieved the maximum extraction yield (Pantoja-Chamorro et al. 2017a, 2017b). These conditions allowed the extraction of major lipids characterized in the preliminary investigation (Pantoja-Chamorro et al. 2017a, 2017b) and minor lipids which were the target aim of this research. The optimization of the extraction conditions had the aim of extracting selectively the medium non-polar compounds; therefore, no cosolvent was employed to increase the polarity of the extraction solvent avoiding the extraction of polar compounds such as phenolic compounds.

The extraction yield for the lipid fraction in the SFE of the passion fruit and blackberry seeds were $15.7 \%$ and $14.5 \%$, respectively. A liquid/liquid extraction of the polar lipids was carried out obtaining a recovery of $1.3 \%$ of the passion fruit SFE extract and $0.9 \%$ for the blackberry extract. These results are comparable to the results obtained with conventional solid/liquid extraction of polar lipids from different fruit seeds. For instance, Saïdani et al. (2004) reported the percentage of polar lipids extracted from other fruit seeds such as blood orange, sweet orange, lemon, and bergamot, obtaining $3.20,1.20,3.30$, and $2.10 \%$, respectively. In another study, the extraction yield of polar lipids was 7.8-9.8\% in seeds from different citric fruits (Waheed et al. 2009). However, there is little information about the polar lipid extraction yield of the seed oils of blackberry and fruit passion.

The use of supercritical $\mathrm{CO}_{2}$ for the extraction of seed oils has important advantages compared to conventional extraction methods, mainly solid-liquid extraction techniques, which use organic solvents toxic to health and environment. Other characteristic disadvantages of these extraction techniques are the high flammability of the solvents for their use in the industry and the traces of solvents remaining in the oils after the extraction processes. Besides, SFE extraction allows a greater selectivity of compounds present in the oil fraction. In fact, slightly higher extraction yields have been obtained for the oil extraction of passion fruit seeds by compressed solvents using propane as extraction solvent at subcritical conditions (Pereira et al. 2017). In that work, and $23.68 \%$ extraction yield was achieved using propane in comparison to the extraction yield achieved in the present work using $\mathrm{CO}_{2}$ $(15.7 \%)$ due to the high affinity of propane to the very nonpolar compounds present in the seeds. Comparing the extraction conditions of both methods, the same temperature resulted optimal for both extractions $\left(60^{\circ} \mathrm{C}\right)$, although softer pressure ( 20 bar) was used for the subcritical propane extraction; however, using propane, longer total extraction time (180 $\mathrm{min}$ ) was needed for obtaining the maximum extraction yield. Moreover, the use of propane as extraction solvent has also some inconvenients such as its flammability and high cost in comparison to $\mathrm{CO}_{2}$ (Akanda et al. 2012) and low solvent power at moderate temperatures (Del Valle \& Aguilera. 1999). Therefore, the application of supercritical $\mathrm{CO}_{2}$ for the extraction of the seed oil of the studied fruits represents a very novel and friendly technique.

\section{Characterization of the Seed Oils from Blackberry and Passion Fruit Obtained Under Supercritical $\mathrm{CO}_{2}$ Conditions}

As mentioned, a complete characterization of the blackberry and passion fruit seed oils was carried out in the present work using GC-MS. LC-DAD-MS/MS analysis were done to corroborate the purity of the extracted fraction confirming that no other kind of compounds were extracted under SFE conditions.

\section{Identification of Lipid Fraction by GC-MS in Seed Oils}

The GC chromatograms of the blackberry (Fig. 1b) and passion fruit (Fig. 1b) seed oils profiles showed that the main compounds present in the seed oils were oleamides, fatty acids and fatty acid derivatives, low-polar phenolic compounds and derivatives, as well as, to a lesser extent, different tocopherols. As expected, TAGs were not detected; therefore, these extracts were considered rich in minority polar compounds. The tentatively identification of the separated compounds of both lipid extracts is summarized in Table 1, together with their relative percentage and LRI values.

Figure 2 depicts the graphical representation of the composition of the seed oils of each fruit (A: blackberry and B: passion fruit). As it can be seen, the most abundant compound 


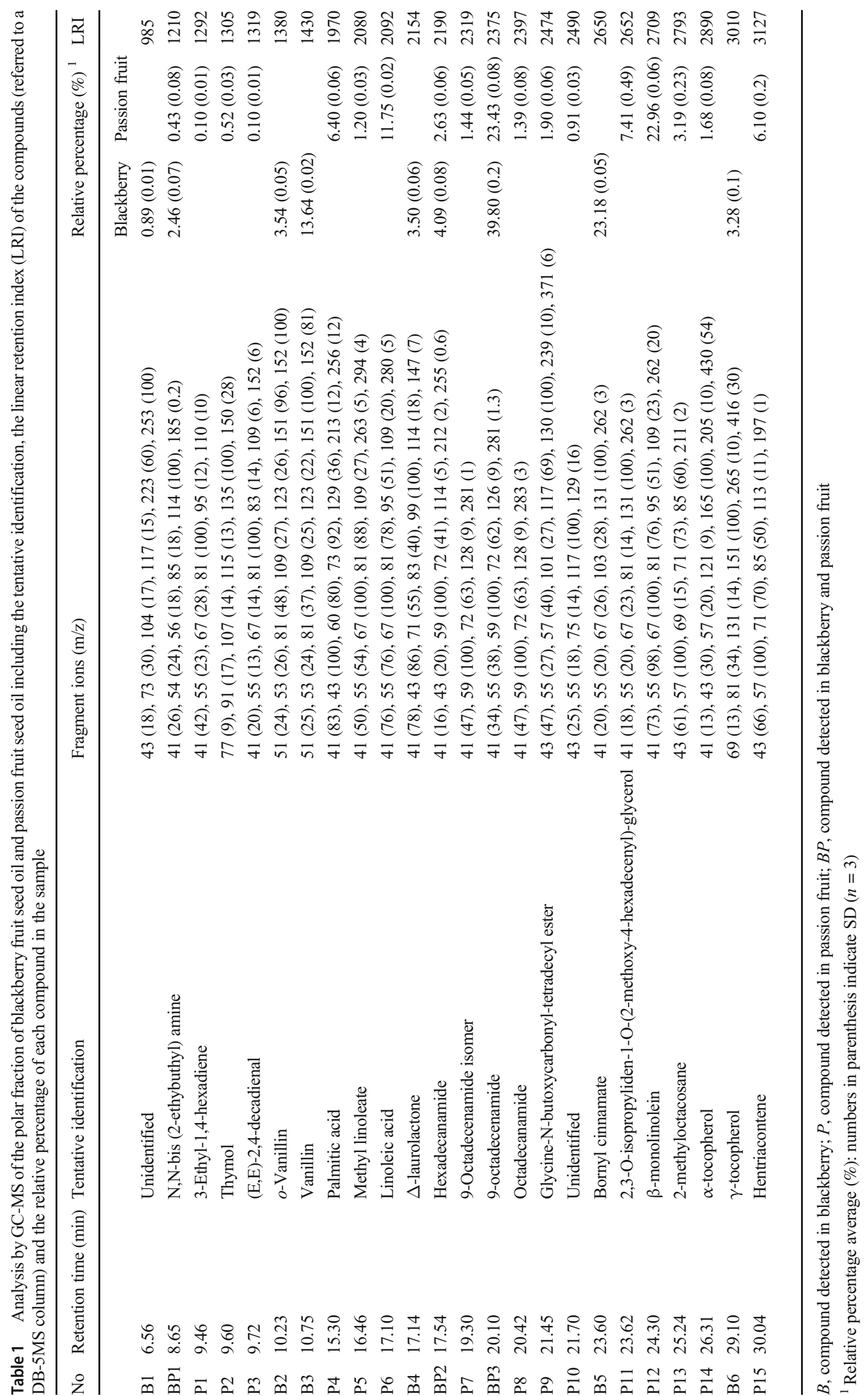


in both samples was 9-octedecenamide (peak BP3 of blackberry and passion fruit analysis (Fig. 1a and b)). The relative percentage of this compound was $23.46 \%$ and $39.8 \%$ in passion fruit and blackberry seed oils, respectively. Besides of 9octedecenamide, other oleamides were identified in the samples: hexadecanamide and octadecanamide.

Comparing the presence of oleamides in the two studied fruits, hexadecanamide appears in both samples (peak BP2), whereas for octadecanamide, three different isomers were detected in passion fruit, including octadecanamide, 9octadecenamide, and an octadecenamide isomer (peaks P7, BP3, and P8), while only 9-octadecenamide was observed in blackberry (peak BP3). The high percentage of 9octedecenamide in the extracts could result of a great interest due to its health-promoting properties, since different biological activities have been reported for this oleamide, such as anti-inflammatory and antibacterial activities (Hadi et al. 2016). Moreover, this oleamide has been identified as an endogenous substance produced by animals to induce sleep and decrease the rate of blood circulation (Abu-Shandi et al. 2015) and has been associated with certain neurological activities, including the regulation of memory processes, the decrease of body temperature and the stimulation of mobility (Driscoll et al. 2007). Some studies have demonstrated the relationship between oleamide and other endogenous lipids in the cannabinoids system (Wu et al. 2007). Besides, Cheng et al. (2010) determined that 9-octadecenamide extracted from Cryptotaenia japonica Hassk seeds had hypolipidemic activity, while Irshad et al. (2020) described that the extracts of Jujube (Ziziphus jujube) were effective against Alzheimer disease due to the presence of oleamide (Heo et al. 2003; Irshad et al. 2020).

Regarding the presence of these compounds in oils, 9octadecenamide, 9-octadecanamide, and tetradecanamide have been detected in the volatile composition of alhidran (Boerhavia elegana Choisy) seed oil, with percentages lower than 1.0\% (Al-Farga et al. 2015). Sankar-Sethi et al. (2016). determined the presence of 9-octadecenamide and octadecanamide in Jatropa seeds, with percentages of 3.0 and $0.8 \%$ respectively. A higher content of oleamide (43.1\%) was determined in Lupinus termis stems from Sudan (Hamed and Ayoub 2015).

Fatty acids also represented an important fraction of the passion fruit seed oil composition. Two main fatty acids were detected in this fruit, mainly palmitic acid and linoleic acid (peaks P4 and P6, respectively). In particular,
Fig. 1 GC-MS of the polar fraction of blackberry (a) and passion fruit (b) seed oils. B, compound detected in blackberry; $\mathrm{P}$, compound detected in passion fruit; BP, compound detected in blackberry and passion fruit. For compound identification see Table 1
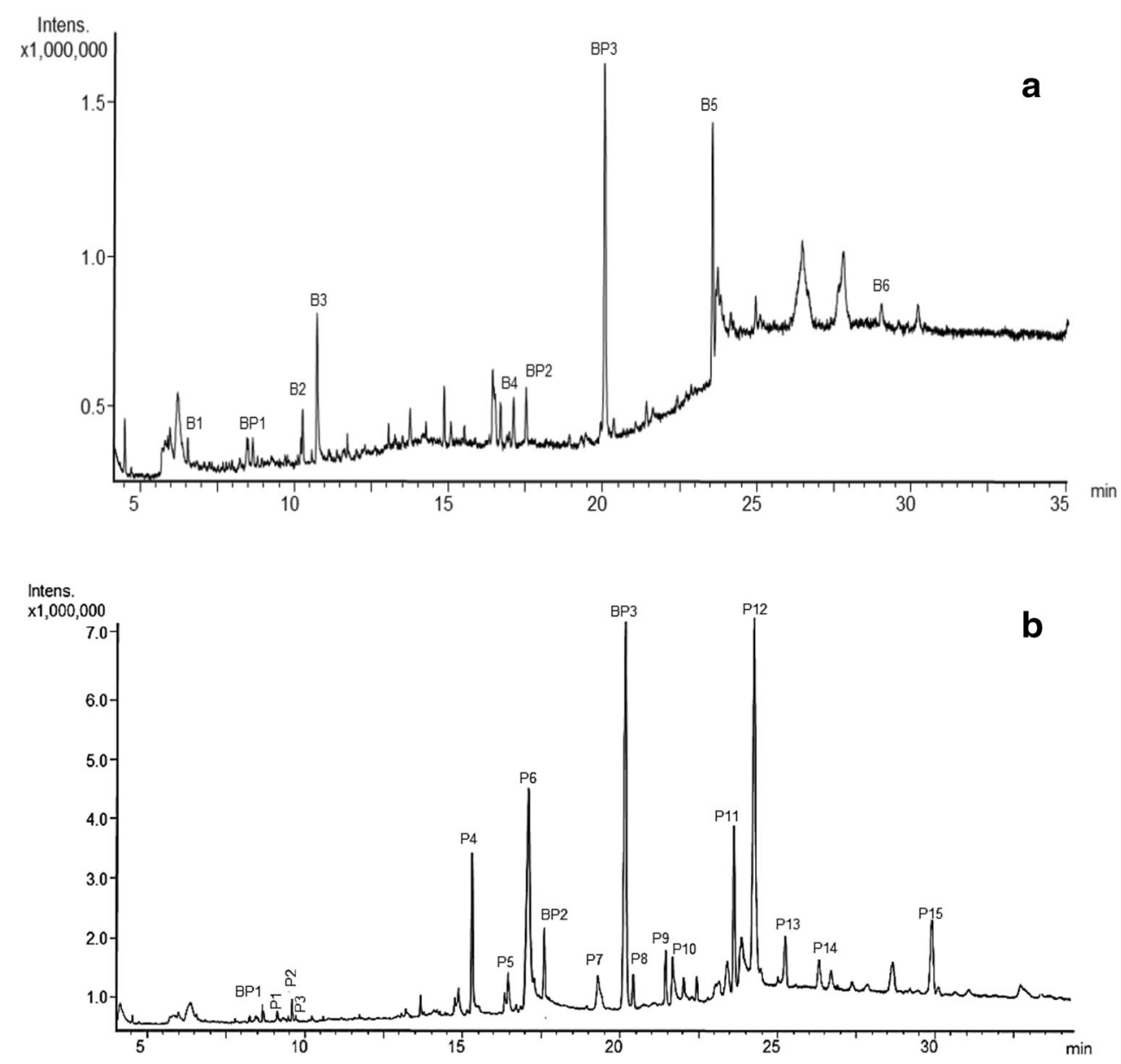
Fig. 2 Graphical representation of the GC-MS chemical characterization of blackberry (a) and passion fruit (b) SFE seed oils extracts. Error bars indicate the $\mathrm{SD}$ of the triplicate analyses

\section{Blackberry}

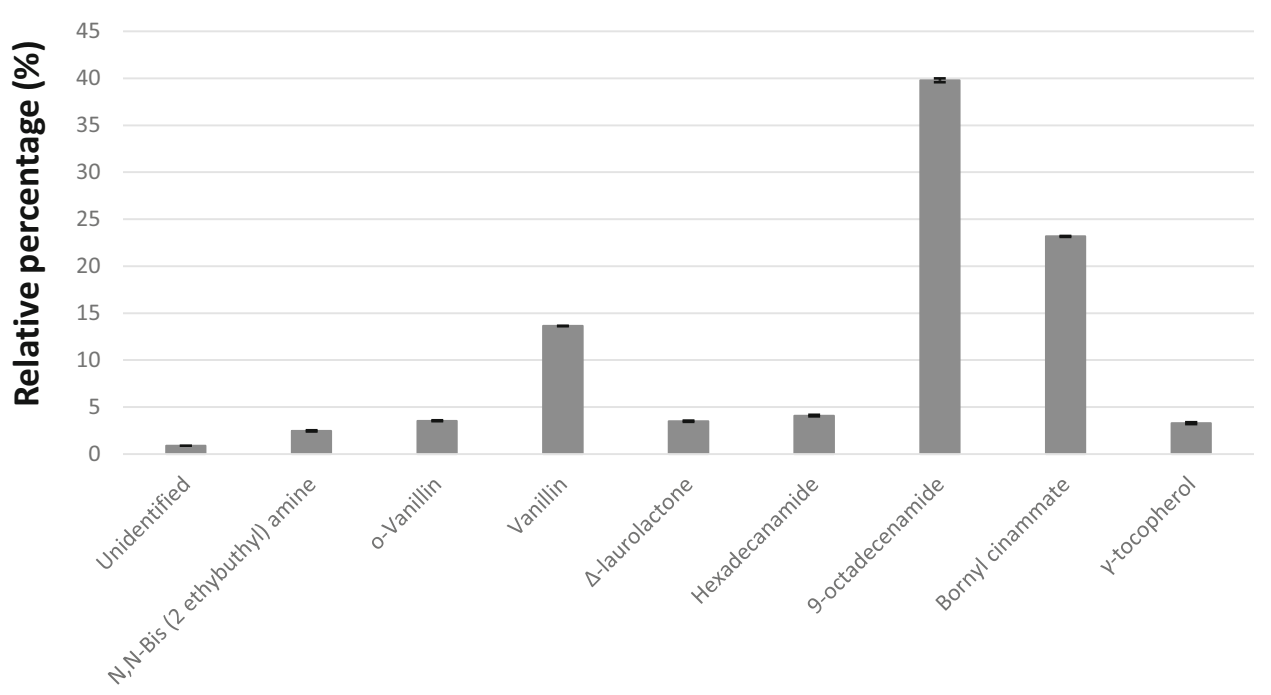

Passion fruit

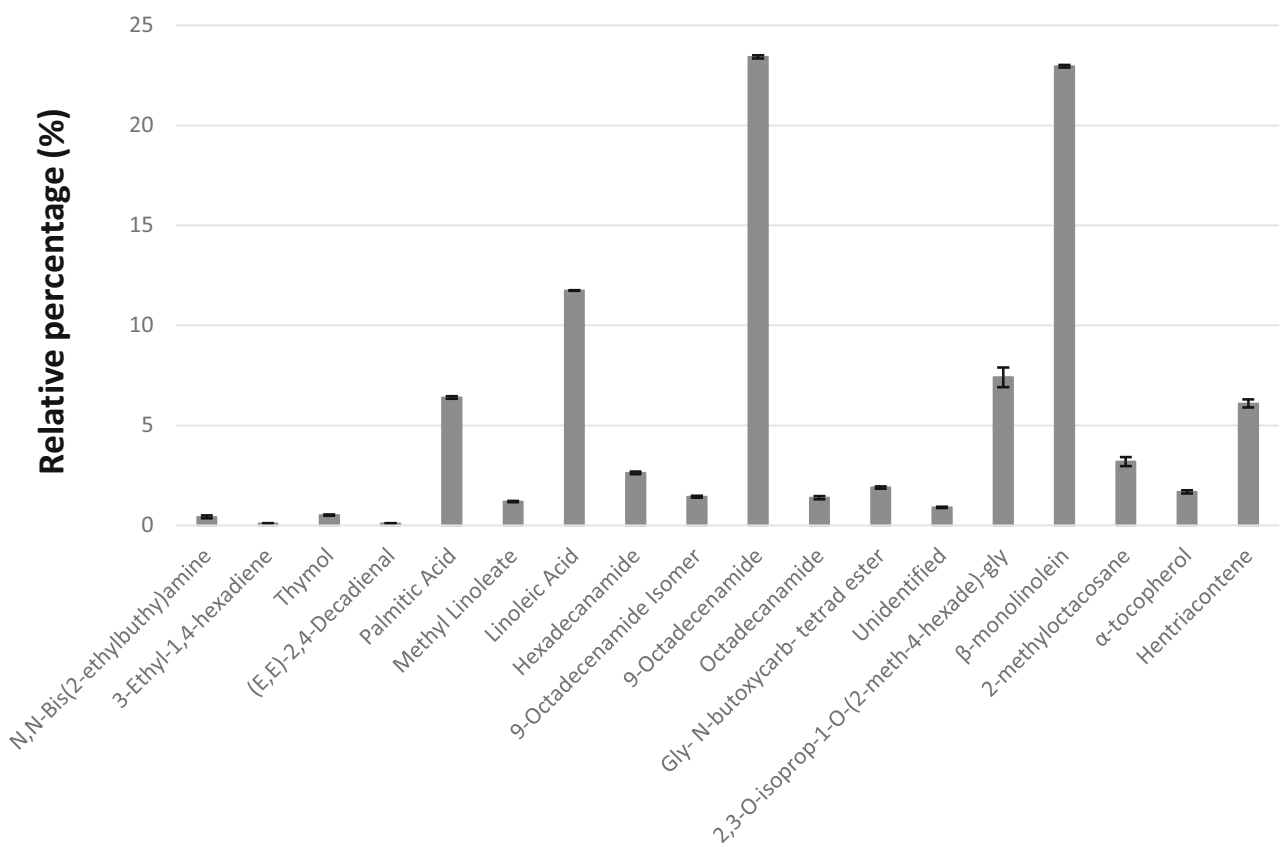

linoleic acid was one of the most abundant compounds in the passion fruit extract. This unsaturated fatty acid is an important compound in human diet since it has properties for prevention of certain cardiovascular diseases (Gupta et al. 2014). Unsaturated fatty acids such as linoleic ( $\omega$ 6) is considered essential components for the structure, development, and function of cells (Otero et al. 2020), and it is related to the reduction of diseases such as cardiovascular, inflammatory, cancer, and metabolic syndrome (González et al. 2016). Bardaa et al. (2016) reported that linoleic acid, as a precursor of arachidonic acid, is important in the inflammatory cascade (prostaglandins, thromboxanes, and leukotrienes). Other beneficial properties for human health and care attributed to linoleic acid are the potential effects on the skin barrier, asthma, arthritis, and multiple sclerosis, and neurological diseases such as Alzheimer's disease or diabetes mellitus (Abedi and Sahari 2014; Tanvir et al. 2018; Vaughn et al. 2018; Su et al. 2015; Higashi et al. 2001; Su et al. 2013). Therefore, linoleic acid is one of the polyunsaturated fatty acids with more important applications for food, cosmetics, and pharmaceutical purposes (Ballesteros-Vivas et al. 2019a).

An interesting fatty acid derivate detected with high intensity in passion fruit seed oil extract was $\beta$ - 
monolinolein (peak P12, 22.96\%). This compound (monoglyceride) derives from linoleic acid and presents a wide range of applications, including food additive, emulsifying, and surfactant (Sagalowicz et al. 2016). Regarding its biological activities, this compound has been related to potent cytotoxic activity on MDA-MB231 breast cancer cells and in use together with stigmasterol it was efficient in inducing tumor regression (Sofi et al. 2018; Sofi 2019).

Interestingly, fatty acids were no detected in blackberry. However, the oil extracted from this fruit presented other important compounds such as low-polar phenolic compounds. In particular, two vanillin isomers (peaks B2 and B3) and a cinnamic acid ester derivative, bornyl cinammate (peak B5). These compounds represented the second family of compounds more abundant in blackberry after the oleamines. Bornyl cinnamate was one of the most abundant compounds in blackberry seed oil, with a percentage of $23.18 \%$. This compound has been previously identified in essential oils of tree leaves employed in the Chinese traditional medicine; for instance, Kumar et al. (2015) reported the anti-inflammatory effect of bornyl cinnamate obtained from Liquidamber formosana leaves. Also, the antileishmanial in vivo activities of this phenolic compound has been reported (Masic et al. 2015).

The presence of vanillin represented the $13.64 \%$ of the oil. In this sense, it is important to emphasize the interesting properties attributed to this compound such as antimutagenic, antineoplasic, anti-inflammatory, antiapoptotic and antioxidant. Other studies have reported its anti-depressant effect (Ueno et al. 2019; Shoeb et al. 2013), comparable to the marketed drug fluoxetine (Anand et al. 2019; Shoeb et al. 2013). This compound has been reported in nopal seeds (Koubaa et al. 2015) as well as in olive oils from different origins (Peres et al. 2016; Brenes et al. 1999; Bianco et al. 2001). Moreover, it has been also identified in cumin seeds (Cuminum cyminum) (Al-Hashemi 2014) and soya seed oil (Schmidt and Pokorný 2005).

The chemical characterization of the two seed oils revealed that the SFE extraction conditions used in this work were adequate for the extraction of medium polar compounds present in the seed fruits. Although both fruits have oleamides as main compound, due to the different nature of the studied fruits, the extracted oils presented different chemical composition. Passion fruit was very rich in fatty acids, in particular, polyunsaturated fatty acids while in blackberry, the presence of low-polar phenolic compounds stood out. Therefore, relative pure extracts were obtained for each fruit with interesting bioactive perspectives for its use in the food, pharmacologic, or cosmetic industry. Moreover, to ensure the purity of these SFE fractions, LC-DAD-MS/MS analysis were carried out.

\section{LC-DAD-MS/MS Analysis of the Seed Oil Extracts}

Several bioactive phenolic compounds have been widely described in the fruit seeds (Fazio et al. 2013; Caruso et al. 2015; De Santana et al. 2017; Castro-Vargas et al. 2019; BallesterosVivas et al. 2019b; Narváez-Cuenca et al. 2020); however, the objective of this work was to apply selective SFE extraction conditions to obtain the polar lipid fraction of the seeds. Therefore, the SFE extracts of blackberry and passion fruit seeds were further investigated by LC-DAD-MS to evaluate the non-co-extraction of other kind of compounds like more polar phenolic compounds.

With this purpose, C18 RP column was chosen for the separation of the possible compounds present in the oil extracts. The information recorded by two different detectors (DAD and MS) was considered for the analysis of this extracts. Typical wavelengths for the detection of phenolic compounds were used, i.e., 280 and $330 \mathrm{~nm}$ as well as optimized MS parameters for phenolic compounds were applied. Figure 3 shows the DAD chromatogram at 280 and $330 \mathrm{~nm}$ and the TIC analysis of both extracts. The optimal conditions chosen for the analysis were long analysis $(75 \mathrm{~min}$ ) and slow gradient to cover all the polarities of possible compounds in a wide retention time. As can be seen in the DAD chromatograms of both extracts, very low abundant peaks were detected at 280 and $330 \mathrm{~nm}$, being the intensity of the higher peak very low in both fruits. Considering the concentration of sample injected in the LC column $(4.5 \mathrm{mg} / \mathrm{mL})$ and the high injection volume $(20 \mu \mathrm{L})$ used, these peaks can be considered as a minimum trace of phenolic compounds.

Moreover, this affirmation was further corroborated with the MS and MS/MS analysis, where these compounds were not ionized, either in positive or negative mode, due to their very low intensity. Along the first $40 \mathrm{~min}$, no peaks were detected and ionized. Only in the more non-polar part of the analysis (48-70 min) high signals were detected, corresponding to non-polar compounds different to phenolic compounds, since they were not detected at 280 and $330 \mathrm{~nm}$ by the DAD.

These results confirmed that the SFE extracts obtained from the studied fruits were rich and pure in potential nonpolar bioactive compounds. Another conclusion of these results is that all the phenolic compounds present in the seeds would remain in the residue of the SFE extraction; therefore, a future work would be the study and optimization of the SFE conditions with the use of modifiers like ethanol, for the extraction of phenolic compounds from this residue, which can be consider lipid and non-polar compounds free. This study would match in a biorefinery approach for the complete recovery of important bioactive compounds in food waste like passion fruit and blackberry seeds. 

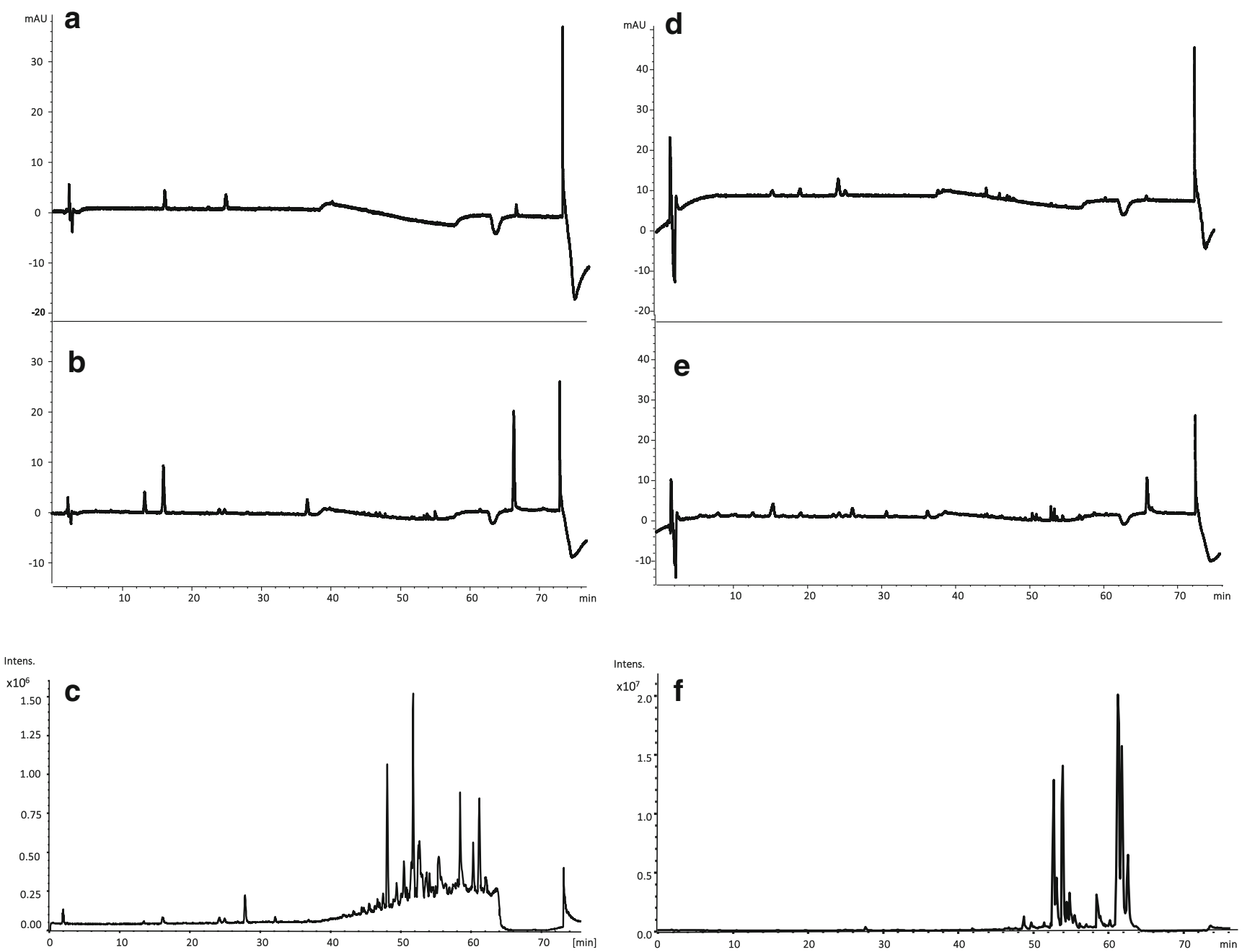

Fig. 3 LC-DAD-MS chromatograms of the polar fraction blackberry and passion fruit. a Chromatogram at $280 \mathrm{~nm}, \mathbf{b}$ chromatogram at $330 \mathrm{~nm}$, and $\mathbf{c}$ TIC of the blackberry sample. d Chromatogram at $280 \mathrm{~nm}$, e chromatogram at $330 \mathrm{~nm}$, and $\mathbf{f}$ TIC of the passion fruit sample

\section{Conclusions}

In this work, a comprehensive extraction and analytical platform has been developed for obtaining a pure polar lipid valuable fraction from two food-by-products, namely passion fruit and blackberry seeds. This platform consisted on the use of the green extraction technique SFE together with two different analytical tools, i.e., GC-MS and LC-DAD-MS. To achieve this goal, the extraction method, previously optimized, was tested in terms of characterization of the final extracts to provide the accurate information about the chemical composition of the valuated extracts. SFE was employed for the selective extraction of the lipid fraction from passion fruit and blackberry seed oils. After the extraction of the polar lipids, a pure fraction of minor polar compounds, free of TAGs, was obtained. GC-MS was applied for carrying out the chemical characterization of the polar fraction. These results revealed three main families of compounds: oleamines, fatty acids, and low-polar phenolic compounds. The main compound found in both seed fruits was 9-octadecenamide. Passion fruit extract was rich in fatty acids, mainly linoleic acid, while blackberry seed oil presented more low-polar phenolic compounds. Besides, LC-DAD-MS/MS analysis showed the purity of the extracts. These extracts could present cosmetic and food interesting properties. Therefore, the use of a green extraction technique as SFE as well as analytical tools that determine the exact composition of the extract is considered useful for the extraction and characterization of, not only bioactive compounds from passion fruit and blackberry seed oils but also for other byproducts of the food industry that can be revaluated.

Authors' Contribution Conceptualization: David Arturo-Perdomo, Juan Pablo Jiménez Mora, Elena Ibáñez, Alejandro Cifuentes, Andrés Hurtado-Benavides, Lidia Montero; methodology: David ArturoPerdomo, Juan Pablo Jiménez Mora, Lidia Montero; formal analysis and investigation: David Arturo-Perdomo, Juan Pablo Jiménez Mora, Elena Ibáñez, Alejandro Cifuentes, Andrés Hurtado-Benavides, Lidia 
Montero; writing - original draft preparation: David Arturo-Perdomo, Lidia Montero; writing - review and editing: David Arturo-Perdomo, Juan Pablo Jiménez Mora, Elena Ibáñez, Alejandro Cifuentes, Andrés Hurtado-Benavides, Lidia Montero; funding acquisition: Elena Ibáñez, Alejandro Cifuentes, Andrés Hurtado-Benavides

Funding Open Access funding enabled and organized by Projekt DEAL. The authors acknowledge funding from the 2014CD0021 project (ICOOP-AGROFOOD 2014) and AGL2017-89417-R project (Spanish Ministry of Science) and Laboratory Department of Universidad de Nariño (Pasto, Colombia).

\section{Declarations}

Conflict of Interest David Arturo-Perdomo declares that he has no conflict of interest. Juan Pablo Jiménez Mora declares that he has no conflict of interest. Elena Ibáñez declares that he has no conflict of interest, Alejandro Cifuentes declares that he has no conflict of interest. Andrés Hurtado-Benavides declares that he has no conflict of interest. Lidia Montero declares that she has no conflict of interest

Open Access This article is licensed under a Creative Commons Attribution 4.0 International License, which permits use, sharing, adaptation, distribution and reproduction in any medium or format, as long as you give appropriate credit to the original author(s) and the source, provide a link to the Creative Commons licence, and indicate if changes were made. The images or other third party material in this article are included in the article's Creative Commons licence, unless indicated otherwise in a credit line to the material. If material is not included in the article's Creative Commons licence and your intended use is not permitted by statutory regulation or exceeds the permitted use, you will need to obtain permission directly from the copyright holder. To view a copy of this licence, visit http://creativecommons.org/licenses/by/4.0/.

\section{References}

Abedi E, Sahari MA (2014) Long-chain polyunsaturated fatty acid sources and evaluation of their nutritional and functional properties. Review Food Sci Nutr 2:443-463. https://doi.org/10.1002/fsn3.121

Abu-Shandi K, Al-Soufi H, Sawalqa M (2015) A quick GC/MS method correlated with LC/MS/MS for the identification of medicinal natural products in Convolvulus arvensis: an injury healing plant. Eurasian J Anal Chem 10:137-149

Amri Z, Lazreg-Aref H, Mekni M, El-Gharbi S, Dabbaghi O, Mechri B, Hammami M (2017) Oil characterization and lipids class composition of pomegranate seeds. Biomed Res Int 2017:2037341. https:// doi.org/10.1155/2017/2037341

Al-Farga A, Zhang H, Siddeeg A, Chamba MVM, Nabil QA (2015) Physicochemical properties, phenolic acids and volatile compounds of oil extracted from dry alhydwan (Boerhavia elegana Choisy) seeds. Grasas Aceites 66:e090. https://doi.org/10.3989/gya.0944142

Al-Hashemi FHY (2014) Chromatographic separation and identification of some volatile oils, organic acids and phenols from the seeds of Cuminum cyminum growing in Iraq. Int J Res Rev Appl Sci 19:80-90

Akanda MJ, Sarker MZ, Ferdosh S, Manap MY, Ab Rahman NN, Ab Kadir MO (2012) Applications of supercritical fluid extraction (SFE) of palm oil and oil from natural sources. Molecules 17: 1764-1794. https://doi.org/10.3390/molecules 17021764

Anand A, Khurana R, Wahal N, Mahajan S, Mehta M, Satija S, Sharma N, Vyas M, Khuranal N (2019) Vanillin: a comprehensive review of pharmacological activities. Plant Arch 19:1000-1004 e-ISSN:2581-6063

Ballesteros-Vivas D, Alvarez-Rivera G, Ibánez E, Parada-Alfonso F, Cifuentes A (2019a) Integrated strategy for the extraction and profiling of bioactive metabolites from Passiflora mollissima seeds combining pressurized-liquid extraction and gas/liquid chromatography-high resolution mass spectrometry. J Chromatogr A 1595:144-157. https://doi.org/10.1016/j.chroma.2019.02.031

Ballesteros-Vivas D, Alvarez-Rivera G, Morantes-Medina SJ, SanchezCamargo AP, Ibánez E, Parada-Alfonso F, Cifuentes A (2019b) An integrated approach for the valorization of mango seed kernel: efficient extraction solvent selection, phytochemical profiling and antiproliferative activity assessment. Food Res Int 126:108616. https:// doi.org/10.1016/j.foodres.2019.108616

Bardaa S, Ben-Halima N, Aloui F (2016) Oil from pumpkin (Cucurbita pepo L.) seeds: evaluation of its functional properties on wound healing in rats. Lipids Health Dis 15:73. https://doi.org/10.1186/ s12944-016-0237-0

Bianco A, Buiarelli F, Cartoni G, Cocciol F, Muzzalupo I, Polidori A, Uccell A (2001) Analysis by HPLC-MS/MS of biophenolic components in olives and oils. Anal Lett 34:1033-1051. https://doi.org/10. 1081/AL-100103612

Bodkowski R, Patkowska-Sokola B, Filip-Psurska B, Kempinska K, Wietrzyk J, Czyz K, Walisiewicz-Niedbalska W, Usydus Z (2014) Evaluation of the anti-proliferative activity of natural lipid preparations against tumor cell lines. J Anim Vet Adv 13:257-266. https:// doi.org/10.36478/javaa.2014.257.266

Brenes M, Garcia A, Garcia P, Rios JJ, Garrido A (1999) Phenolic compounds in Spanish olive oils. J Agric Food Chem 47:3535-3540. https://doi.org/10.1021/jf990009o

Caruso M, Galgano F, Pecora M, Tolve R, Verrastro M, Favati F (2015) Improvement of analytical methods for the determination of polyphenolic bioactive compounds in berry fruits. J Chem 384051:1-6. https://doi.org/10.1155/2015/384051

Castro-Vargas H, Rodriguez-Varela L, Ferreira S, Parada-Alfonso F (2010) Extraction of phenolic fraction from guava seeds (Psidium guajava L) using supercritical carbon dioxide and co-solvents. J Supercrit Fluids 510:319-324. https://doi.org/10. $1155 / 2015 / 384051$

Castro-Vargas H, Baumann W, Ferreira S, Parada-Alfonso F (2019) Valorization of papaya (Carica papaya L.) agroindustrial waste through the recovery of phenolic antioxidants by supercritical fluid extraction. J Food Sci Technol 56:3055-3066. https://doi.org/10. 1007/s13197-019-03795-6

Cheng MC, Ker YB, Yu TH, Lin LY, Peng RY, Peng CH (2010) Chemical synthesis of $9(Z)$-octadecenamide and its hypolipidemic effect: a bioactive agent found in the essential oil of mountain celery seeds. J Agric Food Chem 58:1502-1508. https://doi.org/10.1021/ jf903573g

Cuong TD, Phuong DL, Anh NVT, Khanh PN, Huong TT, Cuong NM (2019) Chemical compositions of Passiflora edulis seed oil cultivated in Vietnam. Vietnam J Sci Technol 57:551-558. https://doi.org/ $10.15625 / 2525-2518 / 57 / 5 / 13801$

De Santana FC, De Oliveira Torres LR, Shinagawa FB, De Oliveira e Silva AM, Yoshime LT, De Melo I, Marcellini PS, Mancini-Filho J (2017) Optimization of the antioxidant polyphenolic compounds extraction of yellow passion fruit seeds (Passiflora edulis Sims) by response surface methodology. J Food Sci Technol 54:3552-3561. https://doi.org/10.1007/s13197-017-2813-3

Dorado D, Hurtado-Benavides AM, Martinez-Correa H (2016) Extracción con $\mathrm{CO}_{2}$ Supercrítico de Aceite de Semillas de Guanábana (Annona muricata): Cinética, Perfil de Ácidos Grasos y Esteroles. Inf Tecnol 25:37-48. https://doi.org/10.4067/S071807642016000500005 
Driscoll WJ, Chaturvedi S, Muller GP (2007) Oleamide synthesszing activity from rat kidney: Identification as Cytochrome C. J Biol Chem 282:22353-22363. https://doi.org/10.1074/jbc.M610070200

Fazio A, Plastina P, Meijerink J, Witkamp R, Gabriele B (2013) Comparative analyses of seeds of wild fruits of Rubus and Sambucus species from Southern Italy: fatty acid composition of the oil, total phenolic content, antioxidant and anti-inflammatory properties of the methanolic extracts. Food Chem 140:817-824. https://doi.org/10.1016/j.foodchem.2012.11.010

Figueroa P, Ceballos M, Hurtado-Benavides AM (2016) Microencapsulación mediante secado por aspersión de aceite de mora (Rubus glaucus ) extraído con $\mathrm{CO}_{2}$ supercrítico. Rev, Colomb, Quim 45:39-47. https://doi.org/10.15446/rev.colomb. quim.v45n2.57481

González A, Martinez M, Paredes A, León A, Ribotta P (2016) Study of the preparation process and variation of wall components in chia (Salvia hispanica L.) oil microencapsulation. Powder Technol 301:868-875. https://doi.org/10.1016/j.powtec.2016.07.026

Gupta S, Shrivastava SK, Shrivastava M (2014) Fatty acid composition of new hybrid varieties of minor millets seed. IIOABJ 5:15-18

Hadi M, Mohammed G, Hameed I (2016) Analysis of bioactive chemical compounds of Nigella sativa using gas chromatography-mass spectrometry. J Pharmacogn Phytother 8:8-24. https://doi.org/10.5897/ JPP2015.0364

Hamed AO, Ayoub SM (2015) Chemical composition and antimicrobial activity of Sudanese Lupinus termis L. root extracts. Pharm Innov 4: 01-04

Heo HJ, Park YJ, Suh YM, Choi SJ, Kim MJ, Cho HY, Chang YJ, Hong B, Kim HK, Kim E (2003) Effects of oleamide on choline acetyltransferase and cognitive activities. Biosci., Biotechnol. Biochem 67:1284-1291. https://doi.org/10.1271/bbb.67.1284

Herrero M, Cifuentes A, Ibañez E (2006) Sub and supercritical fluid extraction of functional ingredients from different natural sources: plants, food-by-products, algae and microalgae: a review. Food Chem 98:136-148. https://doi.org/10.1016/j. foodchem.2005.05.058

Herrero M, Castro-Puyana M, Mendiola JA, Ibañez E (2013) Compressed fluids (SFE, PLE and SWE) for the extraction of bioactive compounds. TrAC-Trends Anal, Chem 43:67-83. https://doi. org/10.1016/j.trac.2012.12.008

Higashi K, Shige H, Ito T, Nakajima K, Ishikawa T, Nakamura H, Ohsuzu F (2001) Effect of a low-fat diet enriched with oleic acid on postprandial lipemia in patients with type 2 diabetes mellitus. Lipids 36:1-6. https://doi.org/10.1007/s11745-001-0660-5

Hiley CR, Hoi PM (2007) Oleamide: A fatty acid amide signaling molecule in the cardiovascular system? Cardiovasc Drug Rev 25:46-60. https://doi.org/10.1111/j.1527-3466.2007.00004.x

Irshad Z, Hanif MA, Ayub MA, Hanif A, Afridi HI (2020) Jujube. In: Hanif MA, Nawaz H, Khan MM, Byrne HJ (ed). Medicinal plants of south Asia. Novel sources for drug discovery, 1st Edn. Elsevier, Amsterdam, pp 451-463

Kitrytė V, Narkevičiūtė A, Tamkutė L, Syrpas M, Pukalskienė M, Venskutonis PR (2020) Consecutive high-pressure and enzyme assisted fractionation of blackberry (Rubus fruticosus L.) pomace into functional ingredients: process optimization and product characterization. Food Chem 312:126072. https://doi.org/10.1016/j. foodchem.2019.126072

Koubaa M, Mhemdi H, Vorobiev E (2015) Seed oil polyphenols: rapid and sensitive extraction method and high resolution-mass spectrometry identification. Anal Biochem 476:91-93. https://doi.org/10. 1016/j.ab.2015.02.025

Kumar KJ, Li J, Vani MG, Hsieh YH, Kuo YH, Wang SY (2015) Bornyl cinnamate inhibits inflammation-associated gene expression in macrophage cells through suppression of nuclear factor- $\mathrm{KB}$ signaling pathway. Planta Med 81:39-45. https://doi.org/10.1055/s-00341383361
Malacrida CR, Jorge N (2012) Yellow passion fruit seed oil (Passiflora edulis f. flavicarpa): physical and chemical characteristics. Braz Arch Biol Technol 55:127-134. https://doi.org/10.1590/S151689132012000100016

Manuel-Barrales F, Alvez C, Martinez J (2015) Supercritical $\mathrm{CO}_{2}$ extraction of passion fruit (Passiflora edulis sp.) seed oil assisted by ultrasound. J Supercrit Fluids 104:183-192. https://doi.org/10.1016/j. supflu.2015.06.006

Masic A, Valencia-Hernandez AM, Hazra S, Glaser J, Holzgrabe U, Hazra B (2015) Cinnamic acid bornyl ester derivatives from Valeriana wallichii exhibit antileishmanial in vivo activity in Leishmania major-infected BALB/c mice. PLoS One 10: e0142386. https://doi.org/10.1371/journal.pone.0142386

Moon SM, Lee SA, Hong JH, Kim JS, Kim DK, Kim CS (2018) Oleamide suppresses inflammatory responses in LPS-induced RAW264.7 murine macrophages and alleviates paw edema in a carrageenan-induced inflammatory rat model. Int. Immunopharmacol 56:179-185. https://doi.org/10.1016/j.intimp. 2018.01.032

Narváez-Cuenca CE, Inampues-Charfuelan ML, Hurtado-Benavides AM, Parada-Alfonso F, Vincken JP (2020) The phenolic compounds, tocopherols, and phytosterols in the edible oil of guava (Psidium guava) seeds obtained by supercritical $\mathrm{CO}_{2}$ extraction. J Food Compos Anal 89:103467. https://doi.org/10.1016/j.jfca. 2020.103467

Nazeam JA, El-Hefnawy HM, Omran G (2018) Chemical profile and antihyperlipidemic effect of Portulaca oleracea L. seeds in streptozotocin-induced diabetic rats. Nat Prod Res 32:1484-1488. https://doi.org/10.1080/14786419.2017.1353507

Oh YT, Lee JY, Lee J, Lee JH, Kim JE, Ha J, Kang I (2010) Oleamide suppresses lipopolysaccharide-induced expression of iNOS and COX-2 through inhibition of NF- $\mathrm{KB}$ activation in BV2 murine microglial cells. Neurosci Lett 474:148-153. https://doi.org/10. 1016/j.neulet.2010.03.026

Opie RS, Itsiopoulos C, Parletta N, Sanchez-Villegas A, Akbaraly TN, Ruusunen A, Jacka FN (2017) Dietary recommendations for the prevention of depression. Nutr Neurosci 20:161-171. https://doi. org/10.1179/1476830515Y.0000000043

Otero D, Antunes B, Bohmer B, Jansen C, Crizel M, Lorini A, Krumreich F, Zambiazi RC (2020) Bioactive compounds in fruits from different regions of Brazil. Rev Chil Nutr 47:31-40. https://doi.org/10.4067/ S0717-75182020000100031

Pantoja-Chamorro A, Hurtado-Benavides AM, Martinez-Correa H (2017a) Caracterización de aceite de semillas de maracuyá (Passiflora edulis Sims) procedentes de residuos agroindustriales obtenido con $\mathrm{CO}_{2}$ supercrítico. Acta Agron 66:178-185. https:// doi.org/10.15446/acag.v66n2.57786

Pantoja-Chamorro A, Hurtado-Benavides AM, Martinez-Correa $\mathrm{H}$ (2017b) Evaluación del rendimiento, composición y actividad antioxidante de aceite de semillas de Mora (Rubus glaucus) extraído con $\mathrm{CO}_{2}$ supercrítico. Inf Tecnol 28:35-46. https://doi. org/10.4067/S0718-07642017000100005

Pereira MG, Hamerski F, Andrade EF, Scheer A, Corazza ML (2017) Assessment of subcritical propane, ultrasound-assisted and Soxhlet extraction of oil from sweet passion fruit (Passiflora alata Curtis) seeds. J Supercrit Fluids 128:338-348. https://doi.org/10.1016/j. supflu.2017.03.021

Peres F, Martins LL, Mourato M, Vitorino C, Antunes P, Ferreira-Diaz S (2016) Phenolic compounds of 'Galega Vulgar' and 'Cobrançosa' olive oils along early ripening stages. Food Chem 211:51-58. https://doi.org/10.1016/j.foodchem.2016.05.022

Ramaiya SD, Bujang JS, Zakaria MH (2019) Physicochemical, fatty acid and antioxidant properties of passion fruit (Passiflora species) seed oil. Pak J Nutr 18:421-429. https://doi.org/10.3923/ pjn.2019.421.429 
Sahena F, Zaidul ISM, Jinap S, Karim AA, Abbas KA, Norulaini NAN, Omar AKM (2009) Application of supercritical $\mathrm{CO}_{2}$ in lipid extraction - a review. J Food Eng 95:240-253. https://doi.org/10.1016/j. jfoodeng.2009.06.026

Saïdani M, Dhifi W, Marzouk B (2004) Lipid evaluation of some Tunisian Citrus seeds. J. Food Lipids 11:242-250. https://doi.org/ 10.1111/j.1745-4522.2004.01136.x

Sagalowicz L, Moccand C, Davidek T, Ghanbari R, Martiel I, Negrini R, Michel M (2016) Lipid self-assembled structures for reactivity control in food. Phil Trans R Soc A 374:20150136. https://doi.org/10. 1098/rsta.2015.0136

Sanchez-Salcedo EM, Sendra E, Carbonell-Barrachina AA, Martinez JJ, Hernandez F (2016) Fatty acids composition of Spanish black (Morus nigra L.) and white (Morus alba L.) mulberries. Food Chem 190:566-571. https://doi.org/10.1016/j.foodchem. 2015.06.008

Sankar-Sethi S, Kumar S, Panda AK, Singh PK (2016) Valorization of Jatropha seed to fuel and chemical feedstock using a thermochemical conversion process. Biofuels 7:429-435. https://doi.org/10. 1080/17597269.2016.1149767

Schmidt Š, Pokorný J (2005) Potential application of oil seeds as sources of antioxidants for food lipids - a review. Czech J Food Sci 23:93102. https://doi.org/10.17221/3377-CJFS

Shoeb A, Chowta M, Pallempati G, Rai A, Singh A (2013) Evaluation of antidepressant activity of vanillin in mice. Indian J Pharm 45:141144. https://doi.org/10.4103/0253-7613.108292

SIOC, Sistema de Información de Gestión y Desempeño de Organizaciones de Cadenas. (2021) Ministerio de Agricultura y Desarrollo Rural de Colombia. https://sioc.minagricultura.gov.co/ Pages/SIOC.aspx. Accessed 20 Feb 2021

Sofi MS (2019) Evaluation of pro-apoptotic effects of $\beta$ monolinolein on metastatic breast cancer cell line MDA-MB231. Asian J Pharm Clin Res 12:235-240. https://doi.org/10. 22159/ajpcr.2019.v12i3.30130

Sofi MS, Sateesh MK, Bashir M, Ganie MA, Nabi S (2018) Chemopreventive and anti-breast cancer activity of compounds isolated from leaves of Abrus precatorius L. 3 Biotech 8:371. https:// doi.org/10.1007/s13205-018-1395-8

Sokoła-Wysoczańska E, Wysoczański T, Wagner J, Czyż K, Bodkowski R, Lochyński S, Patkowska-Sokoła B (2018) Polyunsaturated fatty acids and their potential therapeutic role in cardiovascular system disorders-a review. Nutrients 10:1561. https://doi.org/10.3390/ nu10101561

Su J, Wang H, Ma C, Lou Z, Liu C, Tanver-Rahman M, Nie R (2015) Anti-diabetic activity of peony seed oil, a new resource food in STZinduced diabetic mice. Food Funct 6:2930-2938. https://doi.org/10. 1039/C5FO00507H
Su CH, Lai MN, Ng LT (2013) Inhibitory effects of medicinal mushrooms on $\alpha$-amylase and $\alpha$-glucosidase - enzymes related to hyperglycemia. Food Funct 4:644-649. https://doi.org/10.1039/ c3fo30376d

Sudhahar V, Shaw S, Imig JD (2009) Mechanisms involved in oleamide-induced vasorelaxation in rat mesenteric resistance arteries. Eur J Pharmacol 607:143-150. https://doi.org/10.1016/j. ejphar.2009.02.002

Tanvir R, Javeed A, Rehman Y (2018) Fatty acids and their amide derivatives from endophytes: new therapeutic possibilities from a hidden source. FEMS Microbiol Lett 365:fny114. https://doi.org/10.1093/ femsle/fny114

Ueno H, Shimada A, Suemitsu S, Murakami S, Kitamura N, Wani K, Takahashi Y, Matsumoto Y, Okamoto M, Fujiwara Y, Ishihara T (2019) Comprehensive behavioral study of the effects of vanillin inhalation in mice. Biomed Pharmacother 115:108879. https://doi. org/10.1016/j.biopha.2019.108879

Urbanavičiūte I, Rubinskiene M, Viškelisa P (2019) The fatty acid composition and quality of oils from post-industrial waste of quince Chaenomeles japonica. Chem Biodivers 16:e1900352. https://doi. org/10.1002/cbdv.201900352

Vaughn AR, Clark AK, Sivamani RK, Shi VY (2018) Natural oils for skin-barrier repair: ancient compounds now backed by modern science. Am J Clin Dermatol 19:103-117. https://doi.org/10.1007/ s40257-017-0301-1

Villacís-Chiriboga J, Elst K, Van Camp J, Vera E, Ruales J (2020) Valorization of byproducts from tropical fruits: extraction methodologies, applications, environmental, and economic assessment: a review (Part 1: General overview of the byproducts, traditional biorefinery practices, and possible applications). Compr Rev Food Sci Food Saf 19:405-447. https://doi.org/10. 1111/1541-4337.12542

Waheed A, Mahmud S, Saleem M, Ahmad T (2009) Fatty acid composition of neutral lipid: classes of citrus seed oil. J Saudi Chem Soc 13:269-272. https://doi.org/10.1016/j.jscs.2009.10.007

Wu TT, Charles AL, Huang TC (2007) Determination of the contents of the main biochemical compounds of Adlay (Coxi lachrymal-jobi). Food Chem 104:1509-1515. https://doi.org/10.1016/j.foodchem. 2007.02.027

Zeid IMA, Al Thobaitil SA, EL Hag GA, Alghamdi SA, Umar A, Ahmed Hamdi O (2019) Phytochemical and GC-MS analysis of bioactive compounds from Balanites aegyptiaca. Acta Sci Pharm Sci 3:129134. https://doi.org/10.31080/ASPS.2019.03.0352

Publisher's Note Springer Nature remains neutral with regard to jurisdictional claims in published maps and institutional affiliations. 